\title{
Enchaostics and the Construction of Dynamic Systems
}

\author{
Nilo Sylvio Costa Serpa* \\ ICESP Colleges, Santa Úrsula University, Brazil
}

Submission: April 17, 2018; Published: May 11, 2018

*Corresponding author: Nilo Sylvio Costa Serpa, ICESP Colleges, Santa Úrsula University, Rio de Janeiro, Brazil, Email: niloserpa@gmail.com

\begin{abstract}
This theoretical study promotes materiality to the area of technological research called Enchaostics. It presents and discusses chaotic simulations addressed to understand how an academic environment can evolve from chaos to stabilized states, providing a consistent basis to support new methodological initiatives that promote changes in the current paradigm of education in Brazil. The simulations were treated under specific rules from genetic grammars applied to binary representations for profiles of professors and researchers interacting within a changeresistant environment.
\end{abstract}

Keywords: Chaos; Attractor; Interaction; Self-organization; Simulation; Academic environment; Randomness; Genetic grammars

\section{Introduction}

Enchaostics (Encáostica in Portuguese), the engineering of the chaos (not to confuse with "encaustic", painting technique), is a technology which uses the science of chaos to examine natural or artificial systems to construct, from simulations and experiments on these systems, configurations that prove useful from the point of view of control practices on the dynamics of those systems [1]. It is a proposal initiated and coined by the author [1]. Based on this technology, the study was designed from the classical literature on chaotic systems, from studies on semantics and genetic grammars, and from essays on biology [1-12]. Also, works on education and leadership $[13,14]$ were examined. The main insight was to represent the complexity of an academic environment by a set of differential equations describing the evolution of the relevant variables, such as personal profile (skills, experience, knowledge, ease of communication, creativity, etc.), environmental constraints and so on. These profiles were presented in binary strings with six ordered bits ( 0 or 1 ). The study was placed at Civil Engineering Coordination, ICESP Colleges, Brasília-DF, Brazil, between May 2015 and January 2017, and is underway to validate the preliminary results of the simulations.

\section{Methodology}

I consider, by hypothesis, a system formed hierarchically by the class of professors and researchers of a higher education institution. This hierarchy does not reflect an organization of power; rather, it is referred to acting positions, such as research group leaders, course completion counselors, scientific initiation counselors, etc. The individuals were classified by profiles of ordered six abilities represented by binary strings defining a topology. Such topology fixed the type of the strings and their transcriptions to decimal system. Three differential equations were numerically integrated in convolution to simulate the evolution of the system [12], one of them referred to those strings converted to decimal signatures. I used Maple and R language to perform the simulations. The context of such simulations presupposes a variant of the so-called active methodologies applied to the teaching staff of the institution in focus.

\section{Results}

Simulations showed attractors for different time intervals of iterations. For wide ranges of individual propensities to develop the six abilities described in the work it was observed that the dissimilarities of individual profiles induced attractors with narrow boundaries. Growing the number of individuals, this tendency was maintained. A positive psychological response has been observed among the actors, but the analysis of the results is still on the way. The oscillations that characterize the evolution of the system are related to real competitive fluctuations between the acting forces (in short, resistance to changes versus innovative motivations, taking as a background a collection of individual skills). 


\section{Conclusion}

The study is ongoing. Until now, it showed simulations performed on representations of academic systems consisting of researchers and professors interacting within a change-resistant environment, pointing out that these systems may evolve from chaotic configurations to stability, inducing well defined attractors. Of course, psychological aspects are involved to the extent that the interaction between the actors causes stimuli and personal challenges. Thus, the evolution of the system reflects the intellectual and psychological evolution of its members. It is expected that the tests carried out during the current year will lead to the effective application of the model in question.

\section{Acknowledgement}

The author thanks to ICESP Colleges for the opportunity and support to this research.

\section{Compliance with Ethical Standards}

The author states that this mini-review is part of an entirely original work. This is a research conducted with no conflicts of interests from institutions, colleagues or employees. No copyright was injured. No experiment was led involving humans. The author strongly condemns any kind of predation on other papers, being always alert to any possibility of textual misunderstandings that might give rise to copyright doubts. Now, there is no financial support to this work; the author has sustained the research with its own resources.

\section{References}

1. Din $Q$ (2017) Complexity and chaos control in a discrete-time preypredator model. Commun Nonlinear Sci Numer Simulat 49: 113-134.
2. Gleick J (1991) La Théorie du Chaos. Flammarion, Paris.

3. Haefner J (1996) Modeling Biological Systems: Principles and Applications. Chapman \& Hall, New York, USA.

4. Kauffman S (1993) The Origins of Order. Oxford University Press, New York, USA.

5. Lewin R (1994) Complexidade: A Vida no Limite do Caos. Rio de Janeiro, Brazil.

6. Lorenz E (1993) A Essência do Caos. Editora Universidade de Brasília, Brazil.

7. Mamede S, Penaforte J (2001) Aprendizagem Baseada em Problemas: Anatomia de uma Nova Abordagem Educacional. Hucitec, Fortaleza, Brazil.

8. Mitchell M (2009) Complexity: A Guided Tour. Oxford University Press, New York, USA.

9. Prigogine I (1980) From Being to Becoming: Time and Complexity in the Physical Sciences. WH Freeman and Company, New York, USA.

10. Prigogine I (2002) As Leis do Caos. Editora UNESP, São Paulo. Brazil.

11. Šarlošia J, Bockob J, Suroveca R (2014) Deterministic Chaos. Procedia Engineering 96: 458-466.

12. Serpa N (2012) Computational Simulations and Science: Advanced Lotka-Volterra Modeling in Economics. Int J of Data Analysis \& Information Systems 4(2): 69-80.

13. Serpa N, Alcântara M, Moura E (2017) Encáostica an Engenharia do Caos: Construindo Sistemas Acadêmicos Dinâmicos. Calibre-Revista Brasiliense de Engenharia e Física Aplicada 2(3): 12- 21.

14. Wheatley M (2012) Liderança e a Nova Ciência: Descobrindo Ordem num Mundo Caótico. Cultrix, São Paulo, Brazil.

\section{Your next submission with Juniper Publishers} will reach you the below assets

- Quality Editorial service

- Swift Peer Review

- Reprints availability

- E-prints Service

- Manuscript Podcast for convenient understanding

- Global attainment for your research

- Manuscript accessibility in different formats

( Pdf, E-pub, Full Text, Audio)

- Unceasing customer service

Track the below URL for one-step submission

https://juniperpublishers.com/online-submission.php 